\title{
Obituaries
}

\section{BERNIE KIESER}

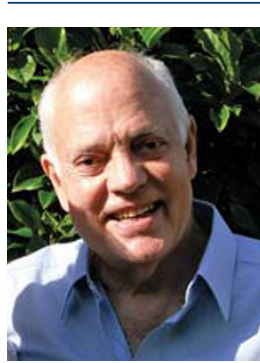

J. Bernard Kieser, (1938-2009) known to most as Bernie, was an internationally renowned periodontal clinician, teacher and researcher. In clinical practice, Bernie was without equal. Many of his patients stayed with him for decades and as a result many became friends, as well as patients. He cared deeply about the welfare of his patients and after his illness was diagnosed last autumn he wrote personally to all his longstanding patients to explain his situation, concerned that he was letting them down in giving up his practice so suddenly. The many replies expressed sadness, admiration, gratitude and love in equal measure. Bernie was renowned for his views on the patient's role in the control of disease and he brilliantly negotiated that fine line between encouragement and chastisement. As one patient put it: 'I always left your practice with a spring in my step, even when you had told me off!' Bernie was a visionary researcher and together with colleagues abroad like the late Sture Nyman he conducted seminal work that is cited to this day. He was renowned for his honesty, his straight-talking, common-sense approach and for his uncompromising and razor-sharp logic.

It's often said that inspirational teachers change the course of people's lives; Bernie was one such teacher. His students were rewarded with an unequalled learning opportunity which shaped their professional careers. He taught clarity of thought and the importance of question- ing received wisdom. He was a superlative communicator and the anecdotes that he used in his teaching became legendary; who can forget dental plaque described as thugs in a football stadium?

Bernie was irascible, irreverent and utterly irreplaceable. He was also refreshingly politically incorrect and was always prepared to put his head above the parapet when most would shelter behind it. His guidance and friendship deeply enriched the lives of his students and his contemporaries. A bright light has been extinguished in dentistry and he will be sorely missed by those who had the privilege of knowing him but especially by Jenny, Sam, Nigel and his grandchildren, to whom he was devoted.

Phil Ower

\section{MAURA FRANCES DUNN}

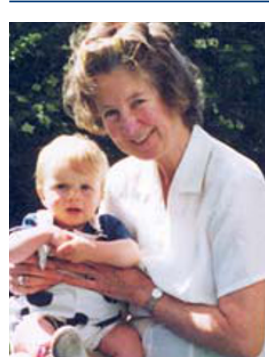

I remember every morning and night, the call through the house 'have you brushed your teeth, have you said your prayers, have you taken your fluoride tablet?' One of Maura's children complained about not having fillings, like his friends.

Born on 31 July 1934, Maura Frances Dunn (née Sweeney) graduated from Glasgow Dental School on 6 July 1957. Maura worked in general dental practice in London for two years and was then Registrar with Gordon Seward - later Professor Seward - in the London Dental Hospital, Whitechapel.

Maura returned to Glasgow to get married on 11 February 1961. Around 1962 she was given a post by Professor
Obituaries should be submitted by email to Kate Maynard at k.maynard@nature.com.

All submitted obituaries should be 350 words maximum in length (apart from obituaries for past presidents of the BDA where the length should be 700-800 words) Content of the obituary is down to the individual author, and the approval of the family should be given for the obituary prior to submission to the $B D J$.

Holmes Hutcheson in the Royal Hospital for Sick Children in Yorkhill, Glasgow, to prevent and treat caries in children attending the leukaemic, haemophilic and cardiac clinics. She developed a lifelong passion in caries prevention.

Professor Ian Donald, the father of ultrasound, gave her one session per week in Yorkhill Maternity, to treat and educate his mothers in the hospital.

In 1970 whilst pregnant with her youngest son, Maura obtained her Fellowship in Dental Surgery in the Royal College of Physicians and Surgeons, Glasgow. In 1986 she became a Consultant in charge of Paediatric Dentistry in Edinburgh Dental Hospital and Sick Children's Hospital. Then in 1994, she was awarded a Fellowship in Dental Surgery without examination, by the Dental Faculty of the Edinburgh Royal College of Surgeons.

She told me when we were engaged that she would have five children, but never specified the number of grandchildren. She had five children and 18 grandchildren at the time of her death, whom she thoroughly enjoyed. After she retired her children and her grandchildren occupied her life.

Her main interests were her caries prevention, photography and natural family planning, an interest she shared with Professor Ian Donald whom she was privileged to know.

Maura died peacefully at home on 2 December 2006, after enduring multisystem atrophy with amazing patience and fortitude, so that all those people who nursed her at home and in the hospice loved her very much.

John J. Dunn 